\title{
Analisis Komparasi Capital Asset Pricing Model dan Fama-French Three Factor Model untuk Penentuan Investasi Pada Saham Indeks IDX30 (Periode 2016-2018)
}

\author{
Nadyah Brhigitta Dwiyuningsih Dotulong ${ }^{1}$ \\ Lanto Miriatin Amali ${ }^{2}$ \\ Selvi $^{3}$ \\ Jurusan Manajemen, Fakultas Ekonomi, \\ Universitas Negeri Gorontalo \\ nadyahdotulong439@gmail.com
}

\begin{abstract}
This research aims to find out Capital Aset Pricing Model and Fama-French Three Factor Model Methods for the investment determination at stock Index IDX30 at period of 2016 to 2018 and to compare the two models concerning which model has a higher level of accuracy to consider the rate of return and its risk. The method used in this research is comparative descriptive with a quantitative approach. Meanwhile, data used are annual financial report of Index IDX30 the period 2016 to 2018. The finding reveals that Capital Aset Pricing Model method is a more accurate model compared to Fama-French Three Factor Model. Besides it has simple look. Capital Asset Pricing Model is more accurate in determining the investment in accordance with the expected rate of return and the risk that is willing to be borne, and this model also provides information as soon as possible regarding the rate of return and risk that will be borne by investors.
\end{abstract}

Keywords: Capital Asset Pricing Model Method, Fama-French Three Factor Model, Ide IDX30

\section{ABSTRAK}

Penelitian ini bertujuan untuk mengetahui Metode Capital Asset Pricing Model dan Fama-French Three Factor Model untuk penentuan investasi pada saham Indeks IDX30 periode 2016 - 2018 serta untuk membandingkan antara dua model tersebut model manakah yang memiliki tingkat akurasi yang lebih tinggi untuk mempertimbangkan tingkat return dan risikonya. Metode yang digunakan dalam penelitian ini adalah deskriptif komparatif dengan pendekatan kuantitatif. Adapun data yang digunakan adalah data berupa laporan keuangan tahunan (annual report) Indeks IDX30 periode 2016 - 2018. Hasil penelitian ini menunjukkan bahwa Metode Capital Asset Pricing Model merupakan model yang lebih akurat dibandingkan Fama-French Three Factor Model. Selain terlihat sederhana, model Capital Asset Pricing Model ini juga lebih akurat dalam menentukan investasi sesuai dengan tingkat pengembalian yang diharapkan dan risiko yang bersedia ditanggung dan model ini dapat memberikan informasi secepat-cepatnya mengenai tingkat pengembalian dan risiko yang akan ditanggung investor.

Kata Kunci : Metode Capital Asset Pricing Model, Fama-French Three Factor Model, dan Indeks IDX30. 


\section{PENDAHULUAN}

Pasar modal Indonesia memiliki peran besar bagi perekonomian negara. Dengan adanya pasar modal (capital market), investor sebagai pihak yang memiliki kelebihan dana dapat menginvestasikan dananya pada berbagai sekuritas dengan harapan memperoleh imbalan (return). Pasar modal adalah pertemuan antara pihak yang memiliki kelebihan dana dengan pihak yang membutuhkan dana dengan cara memperjualbelikan sekuritas (Tandelilin, 2010:26). Keberadaan pasar modal membuat investor mempunyai berbagai pilihan investasi sesuai dengan risiko yang bersedia ditanggung. Dengan adanya pasar modal, investor dapat melakukan diversifikasi investasi dengan cara pembentukkan portofolio sesuai dengan risiko yang bersedia ditanggung dan tingkat keuntungan yang diharapkan. Akan tetapi, masih banyak investor yang melakukan kesalahan dalam pembentukkan portofolio atau pemilihan saham dalam memperhitungkan return dan risiko, sehingga return yang didapatkan tidak sesuai dengan yang diharapkan.

Pada umumnya investor mengharapkan keuntungan yang sebesar-besarnya dari dana yang diinvestasikan. Semakin besar keuntungan yang diharapkan, maka semakin besar pula risiko yang dihadapi oleh investor. Calon investor yang berencana untuk melakukan investasi di pasar modal dalam bentuk saham, harus berhati-hati dalam memilih emiten saham. Investor dapat memilih saham dengan mempertimbangkan return dan risikonya. Hal tersebut dapat dilakukan menggunakan model-model keseimbangan yang pada dasarnya membantu investor dalam menentukan pengukur risiko yang relevan terhadap suatu aset serta hubungan risiko dan return yang diharapkan. Model-model yang bisa digunakan seperti Capital Asset Pricing Model (CAPM), Arbitrage Pricing Theory (APT), dan Fama-French Three Factor Model. Adapun dalam penelitian ini menggunakan Capital Asset Pricing Model (CAPM) dan Fama-French Three Factor Model.

Capital Asset Pricing Model (CAPM) pertama kali dikenalkan oleh Sharpe, Lintner, dan Mossin pada pertengahan tahun 1960-an. CAPM merupakan suatu model yang menghubungkan tingkat return harapan dari suatu asset berisiko dengan risiko dari asset tersebut pada kondisi pasar yang seimbang (Tandelilin, 2010:187). Pada CAPM, portofolio pasar sangat berpengaruh karena diasumsikan bahwa risiko yang relevan adalah risiko sistematis yang diukur dengan beta (tingkat sensitivitas return sekuritas terhadap 
perubahan return pasar). Oleh karena itu, CAPM sebagai salah satu model keseimbangan dapat membantu untuk menyederhanakan gambaran nyata hubungan antara risk dan return.

Fama-French Three Factor Model melihat hubungan risk dan return berdasarkan tiga faktor, yaitu market return, firm size, dan book to market equity. Faktor-faktor yang diusulkan Fama \& French sebagai variabel yang mempengaruhi return portofolio adalah book-to-market dan ukuran perusahaan (size), pada Model Tiga Faktor Fama \& French terdapat faktor HML (High Minus Low) dan SMB (Small Minus Big) yang diperoleh dan pengelompokkan return saham-saham yang memiliki book-to-market tinggi $(\mathrm{H})$, sedang (M), dan rendah (L) dan pengelompokkan return saham yang memiliki ukuran perusahaan kecil (S) dan besar (B).

Suatu indeks diperlukan sebagai sebuah indikator untuk mengamati pergerakan harga dari sekuritas-sekuritas. Sampai sekarang, Bursa Efek Indonesia (BEI) mempunyai 15 indeks, yaitu indeks harga saham gabungan (IHSG), indeks liquid 45 (ILQ-45), indeks-indeks IDX (Indonesia Stock Exchange) Sektoral, indeks Jakarta Islamic Index (JII), indeks Papan Utama dan Indeks Papan Pengembangan, indeks kompas 100, indeks BISNIS-27, indeks PEFINDO25, indeks SRI-KEHATI, indeks Saham Syariah Indonesia (Indonesia sharia Stock Index atau ISSI), dan Indeks IDX30, Infobank 15, Smintra 18, MNC36, Investor 33 (Hartono, 2017:166). Adapun dalam penelitian ini menggunakan Indeks IDX30.

Indeks IDX30 diluncurkan pada tanggal 23 April 2012 yang berisi 30 saham kapitalisasi terbesar di LQ45. Pemilihan saham dilakukan setiap 6 bulan, yaitu pada awal bulan Februari dan Agustus. Jumlah konstituen Indeks IDX30 yang terdiri dari 30 saham memiliki keunggulan lebih mudah dilakukan replika sebagai acuan portofolio. Kriteria pemilihan saham di IDX30 adalah nilai transaksi, frekuensi transaksi, total hari transaksi dan tentu saja kapitalisasi pasarnya. Berikut Grafik Interaktif Indeks IDX30 periode 20162018. 


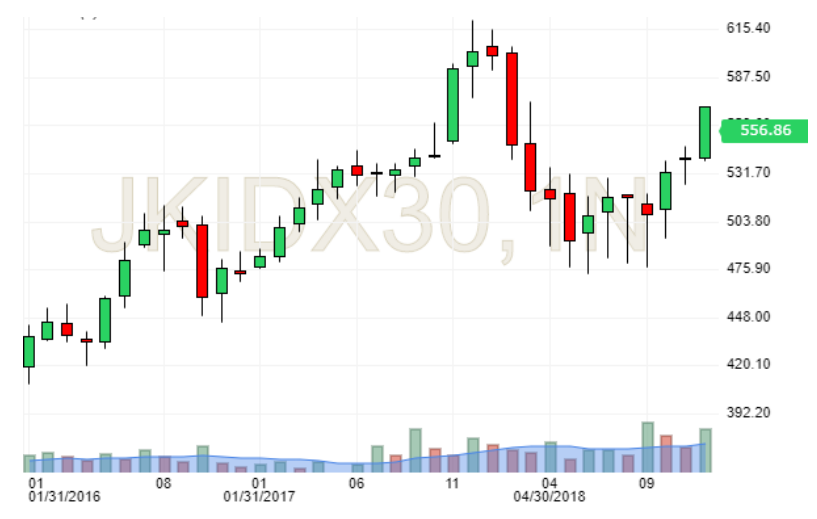

Gambar 1. Grafik Interaktif Indeks IDX30 2016-2018

Sumber : Investing.com

Berdasarkan grafik di atas menunjukkan bahwa Indeks IDX30 selama tahun 20162018 mengalami fluktuasi. Hal tersebut terlihat pada tahun 2016 Indeks IDX30 dibuka ratarata pada level 463.72, berada pada level terendah 450.737, level tertinggi 480.145 dan ditutup rata-rata pada level 467.172. Pada tahun 2017 Indeks IDX30 dibuka rata-rata pada level 527.530, berada pada level terendah 520.245, level tertinggi 544.995, dan ditutup rata-rata pada level 536.028 dan pada tahun 2018 Indeks IDX30 dibuka rata-rata pada level 536.387, berada pada level terendah 507.169, level tertinggi 550.972, dan ditutup ratarata pada level 531.634 .

Maka dalam penelitian ini kedua model di atas yaitu Capital asset pricing model (CAPM) dan Fama-French three factor model untuk penentuan investasi serta untuk membandingkan diantara dua model tersebut model manakah yang memiliki tingkat akurasi yang lebih tinggi untuk mempertimbangkan tingkat return dan risikonya. Tidak hanya menggunakan kepekaan investor, tetapi juga menggunakan aspek kuantitatif seperti kondisi keuangan, prospek pertumbuhan, dan faktor-faktor lain yang berhubungan dengan pertumbuhan perusahaannya. Atas dasar pemikiran di atas maka dalam penelitian ini peneliti mengambil judul " Analisis Komparasi Capital Asset Pricing Model dan FamaFrench Three Factor Model untuk Penentuan Investasi pada Saham Indeks IDX30 Periode 2016 - 2018." 


\section{METODE PENELITIAN}

\section{A. Tempat dan Waktu Penelitian}

Untuk mendapatkan data yang diperlukan pada penelitian ini, peneliti mengambil data di Galeri Investasi Bursa Efek Indonesia UNG serta di Website resmi Bursa Efek Indonesia (www.idx.co.id), Website yahoo finance, Website Bank Indonesia dan mengambil objek pada perusahaan yang terdaftar dalam Indeks IDX30, data penelitian ini di mulai pada $2016-2018$.

\section{B. Desain Penelitian}

Jenis penelitian yang digunakan dalam penelitian ini adalah deskriptif komparatif dengan pendekatan kuantitatif. Sugiyono (2012:54) menyatakan bahwa penelitian komparatif adalah penelitian yang membandingkan keberadaan satu variabel atau lebih pada dua atau lebih sampel yang berbeda, atau pada waktu yang berbeda.

\section{Populasi dan Teknik Pengambilan Sampel}

Populasi yang digunakan pada penelitian ini adalah perusahaan yang terdaftar dalam Indeks IDX30. Penentuan sampel dalam penelitian ini menggunakan tehnik purposive sampling yaitu tehnik penentuan sampel yang digunakan dengan pertimbangan tertentu. Pengambilan sampel pada penelitian ini adalah berdasarkan kriteria sebagai berikut :

1. Perusahaan yang konsisten terdaftar di Indeks IDX30 pada periode 2016 - 2018.

2. Perusahaan yang laporan keuangannya terdaftar di Bursa Efek Indonesia pada periode $2016-2018$.

\section{Sumber Data dan Teknik Pengumpulan Data}

Penelitian ini menggunakan data sekunder, dimana sumber data penelitian ini diperoleh dari Website Bursa Efek Indonesia (www.idx.co.id), Website Yahoo Finance, Website Bank Indonesia berupa data perusahaan yang tergabung dalam Indeks IDX30 periode $2016-2018$.

Teknik pengumpulan data yang digunakan pada penelitian ini adalah studi kepustakaan. Penelitian studi kepustakaan dilakukan dengan mempelajari literatur- 
literatur yang ada berupa jurnal-jurnal penelitian, penelitian terdahulu, buku-buku pustaka, dan sumber-sumber lainnya yang berhubungan dengan bidang yang diteliti.

\section{E. TeknikAnalisis Data}

1. Pembentukkan Portofolio Optimal dengan Single Index Model
a. Menghitung Actual dan Expected Return Saham Individual
b. Menghitung Actual dan Expected Return Pasar
c. Menghitung Standar Deviasi saham dan Standar Deviasi Pasar
d. Menghitung Beta Saham
e. Menghitung Alpha Saham
f. Menghitung Varians dari Kesalahan Residu
g. Menghitung Return Aset Bebas Risiko
h. Menghitung Excess Return to Beta
i. Menghitung Cut Off Point
j. Melakukan Pembobotan Saham
k. Menghitung Expected Return Portofolio
I. Menghitung Standar Deviasi Portofolio

2. Fama-French Three Factor Model
a. Premi Risiko
b. Size (Ukuran Perusahaan)
c. Book to Market Equity Ratio
d. Membentuk Portofolio SMB
e. Membentuk Portofolio HML

\section{HASIL PENELITIAN}

Model Capital Asset Pricing Model menjelaskan hubungan return dan risiko hanya ditentukan oleh nilai Beta. Sedangkan Metode Fama-French Three Factor Model melihat hubungan return dan risikonya dengan menentukan Premi Risiko, Size (Ukuran Perusahaan), Book to Market (BM) dan Membentuk Portofolio Small Minus Big (SMB) dan High Minus Low (HML).

Model Capital Asset Pricing Model hanya menggunakan variabel beta untuk mengestimasi return saham maka hasil estimasi return saham yang dihasilkan kurang 
akurat. Tetapi metode ini dapat digunakan investor untuk perhitungan jangka pendek, data yang dibutuhkan mudah untuk didapatkan dan untuk mendapatkan hasil estimasi return saham tidak membutuhkan waktu yang banyak.

Model Fama-French Three Factor Model dalam mengestimasi return lebih akurat karena Fama-French Three Factor Model menggunakan empat factor yaitu Premi Risiko, Size (Ukuran Perusahaan), Book to Market (BM) dan Membentuk Portofolio Small Minus Big (SMB) dan High Minus Low (HML). Tetapi, data yang dibutuhkan cukup banyak dan beberapa data sulit untuk didapatkan secara terbuka dan membutuhkan waktu yang cukup lama dalam melakukan perhitungan hasil estimasi return saham dengan menggunakan model Fama-French Three Factor Model.

Berdasarkan hasil penelitian, Capital Asset Pricing Model merupakan model yang lebih akurat dibandingkan Fama-French Three Factor Model. Selain terlihat sederhana, model Capital Asset Pricing Model ini juga lebih akurat dalam menentukan investasi sesuai dengan tingkat pengembalian yang diharapkan dan risiko yang bersedia ditanggung dan model ini dapat memberikan informasi secepat-cepatnya mengenai tingkat pengembalian dan risiko yang akan ditanggung investor.

\section{SIMPULAN}

Berdasarkan penelitian yang telah dilakukan maka didapatkan kesimpulan sebagai berikut :

A. Penentuan investasi saham pada Indeks IDX30 dengan menggunakan Metode Capital Asset Pricing Model menghasilkan 7 kandidat portofolio. Saham yang terpilih menjadi kandidat portofolio dengan bobot alokasi tertinggi adalah United Tractor Indonesia, Tbk (UNTR) dengan alokasi mencapai 30,1\% dari total portofolio. Selanjutnya adalah saham Perusahaan Gas Negara, Tbk (PGAS) dengan bobot sebesar 27,2\%, Aneka Tambang, Tbk (ANTM) dengan bobot sebesar 12,3\% dan Adaro Energy, Tbk (ADRO) dengan bobot sebesar $11 \%$ dari total portofolio. Adapun saham yang memiliki bobot alokasi di bawah 10 persen adalah Waskita Karya, Tbk (WSKT) dengan bobot 8,8\%, Bank Central Asia, Tbk (BBCA) dengan bobot sebesar 7,4\% dan Astra Internasional Indonesia, Tbk (ASII) dengan bobot alokasi sebesar 3,2\% dari total portofolio. Nilai return portofolio sebesar 0,226 atau $22,6 \%$ jika dibandingkan dengan nilai return IHSG, 
nilai return portofolio jauh lebih tinggi dibandingkan dengan return IHSG. Nilai risiko portofolio sebesar $40,2 \%$ jika dibandingkan dengan nilai risiko IHSG, nilai risiko portofolio masih lebih tinggi dibandingkan dengan risiko IHSG yang hanya sebesar $1,9 \%$. Dengan kata lain, return portofolio yang dibentuk dengan menggunkan Metode Single Index ini lebih dibandingkan dengan rata-rata pasar.

B. Penentuan investasi saham pada Indeks IDX30 dengan menggunakan Metode FamaFrench Three Factor Model dapat disimpulkan bahwa portofolio yang memberikan return yang paling maksimal adalah Portofolio Big High pada tahun 2016 sebesar 65,8\%, pada tahun 2017 sebesar 23,1\% dan pada tahun 2018 returnnya sebesar $-8,1 \%$ yaitu saham Bank Negara Indonesia (Persero) Tbk (BBNI), Bank Mandiri (Persero) Tbk (BMRI), Perusahaan Gas Negara (Persero) Tbk (PGAS) dan Adaro Energy Tbk (ADRO). Portofolio yang memiliki kinerja terbaik selanjutnya adalah portofolio Big Low pada tahun 2016 sebesar 20,4\%, pada tahun 2017 sebesar 32,9\% dan pada tahun 2018 returnnya sebesar $-6,6 \%$. Sementara portofolio yang memiliki kinerja terburuk adalah portofolio Small Low pada tahun 2016 sebesar 51,5\%, pada tahun 2017 sebesar -7,3\% dan pada tahun 2018 returnnya sebesar $-19,7 \%$.

C. Metode Capital Asset Pricing Model dan Fama-French Three Factor Model merupakan model yang dapat membantu investor dalam menentukan pengukur risiko yang relevan terhadap suatu asset serta hubungan risiko dan return yang diharapkan. Berdasarkan hasil penelitian, Metode Capital Asset Pricing Model lebih akurat dibandingkan Metode Fama-French Three Factor Model selain metode Capital Asset Pricing Model lebih sederhana metode ini juga lebih akurat dalam menentukan investasi sesuai dengan tingkat pengembalian yang diharapkan dan risiko yang bersedia ditanggung.

\section{SARAN}

A. Bagi Peneliti Selanjutnya

Peneliti selanjutnya yang meneliti mengenai Analisis Komparasi Capital Asset Pricing Model dan Fama-French Three Factor Model untuk penentuan investasi diharapkan dapat memilih sampel yang berbeda sehingga dapat memperkaya ilmu mengenai penelitian ini. 
B. Bagi Investor dan Calon Investor

Investor maupun calon investor yang ingin melakukan investasi pada saham sebaiknya melakukan analisa saham sebelum melakukan pengambilan keputusan dalam berinvestasi. Analisa dengan menggunakan berbagai metode seperti Metode Capital Asset Pricing Model dan Fama-French Three Factor Model diperlukan agar dapat mengetahui saham yang mampu memberikan return atau tingkat pengembalian yang lebih besar daripada yang diharapkan.

\section{DAFTAR PUSTAKA}

Arikunto, Suharsimi. (1998) "Prosedur Penelitian Suatu Pendekatan Praktek". Jakarta : PT. Rineka Cipta.

Blanco, Belen. (2012) "The Use Of CAPM And Fama French Three Factor Model: Portofolios Selection". Public and Muncipal Finance, Volume 1, Issue 2.

Brigham, Eugene F dan Houston. (2006) "Fundamental of Financial Management: Dasar-Dasar Manajemen Keuangan", Jakarta: Edisi 10, Salemba Empat.

Fahmi, Irham. (2016). "Manajemen Risiko". Bandung : Alfabeta

Harjito, D. Agus dan Martono. (2012). “Manajemen Keuangan”. Yogyakarta : Ekonisia

Hanafi, Mamduh. (2004). “Manajemen Keuangan". Yogyakarta: BPFE

Husnan, Suad. (2005). "Dasar-Dasar Teori Portfolio dan Analisis Sekuritas". Yogyakarta: UPP AMP YKPN.

Husnan, Suad. (2008). "Manajemen Keuangan: Teori dan Penerapan". Yogyakarta: BPFE.

Husnan, Suad. (2013). "Manajemen Keuangan Teori dan Penerapan (keputusan jangka panjang)". Yogyakarta : BPFE

Husnan, Suad. (2015). "Dasar-Dasar Teori Portofolio \& Analisis Sekuritas". Yogyakarta : UPP STIM YKPN

Hartono, Jogiyanto. (2017). "Teori Portofolio dan Analisis Investasi". Yogyakarta : BPFE

Hartono, Jogiyanto. (2012). "Teori Portofolio dan Analisis Investasi", Yogyakarta: BPFE.

Ilona Cherie, Darminto, Devi Farah. (2014). "Penerapan Metode CAPM (Capital Asset Pricing Model) untuk Menentukan Pilihan Investasi pada Saham. Jurnal Administrasi Bisnis Vol. 13 No.

http://administrasibisnis.studentjournal.ub.ac.id/index.php/jab/article/view/554/753

Inge Lengga Sari Munthe, SE.Ak., M.Si; Firmansyah Kusasi, ST., MM; Nurfatilla Afidah. (2016). "Analisis perbandingan keakuratan capital asset pricing model (capm) dan arbitrage 
pricing theory (apt) dalam memprediksi return saham". http://jurnal.umrah.ac.id/wpcontent/uploads/gravity forms/1ec61c9cb232a03a96d0947c6478e525e/2017/08/JURNAL-NURFATILLA-AFIDAH.pdf

Laporan keuangan resmi Indeks IDX30 yang diakses melalui situs Bursa Efek Indonesia (www.idx.co.id)

Neneng Susanti. (2013). "Pengujian fama french three factor model pada perusahaan di indonesia. Jurnal Forum Keuangan \& Bisnis II". https://repository.widyatama.ac.id/xmlui/bitstream/handle/123456789/4284/CONTENT\% 20NENENG\%20SUSANTI.pdf?sequence $=2$

Ni Putu Desy Ratna Dewi, I Wayan Suartana. (2018). "Komparasi capital asset pricing model dan fama-french three factor model dalam memprediksi return saham". E-Jurnal Ekonomi dan Bisnis Universitas Udayana 7.3. file:///C:/Users/Asus/Downloads/36543-109-78837-110-20180421\%20(1).pdf

Nilai Sertifikat Bank Indonesia (SBI) di peroleh dari laporan resmi Bank Indonesia yang diakses melalui situs (www.bi.go.id)

Sjahrial, Dermawan. (2014). "Manajemen Keuangan Lanjutan", Edisi Revisi, Jakarta : Mitra Wacana Media

Tandelilin, Eduardus. (2010). "Portofolio dan Investasi". Yogyakarta : Kanisius

Ully Rakhmawati, Maswar Patuh Priyadi. (2015). "Analisis Three Factor Fama And French Model Dan Capital Asset Pricing Model". Jurnal Ilmu \& Riset Akuntansi Vol. 4 No. 8. https://studylibid.com/doc/1164997/analisis-three-factor-fama-and-french-model-dancapital-a..

Zubir, Zalmi. (2011). "Manajemen Portofolio: Penerapannya dalam Investasi Saham", Jakarta: Salemba Empat. 